\title{
Time to Quantify Turkey's Foreign Affairs: Setting Quality Standards for a Maturing International Relations Discipline ${ }^{1}$
}

\author{
Ersel Aydinli \\ Bilkent University \\ AND \\ Gonca Biltekin \\ Center for Foreign Policy and Peace Research Ankara
}

\begin{abstract}
The first part of this article discusses the current state of International Relations (IR) in Turkey and begins with the argument that the local disciplinary community shows a lack of adequate communication and interactive scholarly debates, and therefore of knowledge accumulation. This article proposes that the growth of such engagement could be encouraged by increased methodological diversity, in particular additional research using quantitative methods. It argues that quantitative research could contribute to engagement by providing conceptual and methodological clarity around which scholarly debates could develop and ultimately contribute to Turkish IR's progress as a disciplinary community. To substantiate these claims, this article goes on to discuss the development and contributions of quantitative research to global IR and illustrates the potential benefits of using quantitative methods in the study of Turkish foreign affairs.
\end{abstract}

Keywords: quantitative research, Turkey, foreign affairs, methodology

Turkish International Relations (IR) is a growing discipline both in terms of the number of researchers working within it and the broadness of subjects being covered. Particularly in the last decade, IR publications by scholars based in Turkey have reached unprecedented levels. A quick search through the Web of Science for articles in the areas of political science (PS), IR, or area studies (AS), with authors providing a Turkish address, confirms this observation. ${ }^{2}$

Although such proliferation is welcome in many respects, it is reasonable to ask whether those sheer numbers have contributed to an improved understanding of the subject matters and whether they reflect a growing sense of local disciplinary identity. In this article, we argue that this proliferation can only be fruitful if it generates debates within the community. Moreover, such debates are possible and progressive only if there is sufficient theoretical and methodological diversity. To support our argument, we highlight the current state of Turkish IR as observed by leading local scholars and as suggested by both the findings of a recent

\footnotetext{
${ }^{1}$ The data set used for the analysis here is archived at Aydinli, Ersel, and Biltekin, Gonca (2015), "Replication Data for Time to Quantify Turkey's Foreign Affairs: Setting Quality Standards for a Maturing International Relations Discipline," http://dx.doi.org/10.7910/DVN/P6CPAF, Harvard Dataverse, V1.

${ }^{2}$ The exact search term used was $\mathrm{WC}=$ political science $\mathrm{OR}$ area studies $\mathrm{OR}$ international relations AND $\mathrm{AD}=$ Turkey and document types: (article). Timespan: All years. Indexes: SCI-EXPANDED, SSCI.
} 
Teaching, Research, and International Politics (TRIP) survey and by our review of the research published in four leading journals of Turkish IR. We argue that, in contrast to what has been claimed informally, it is not the lack of theoretical diversity that impedes debates but a lack of methodological diversity. Our findings suggest that Turkish IR is predominantly qualitative and that this uniformity of methodology ultimately impedes debate. The lack of debate, in turn, hinders both community building and the accumulation of knowledge.

First, the article looks at the current state of Turkish IR and reveals a fragmented community with limited scientific interaction-as evidenced by the observations of leading scholars, co-authorship ratios, and citation counts. Second, we argue that one of the major reasons for such fragmentation is the lack of methodological diversity. Based on a survey of 251 IR articles by scholars based in Turkey and published in four journals, we find a predominant use of similar, mostly qualitative, methods. We argue that, in the case of a very young and underdeveloped disciplinary community like that of Turkish IR, the use of more quantitative methods $^{3}$ would help to generate debates and engagement among members, thereby benefitting the discipline in three inter-related ways:

1. On the empirical level, Turkish IR scholars would be encouraged to better define concepts, which would lead to more meaningful debates.

2. On the social level, long-term research programs specially designed to generate data would help establish a sense of community.

3. On the methodological level, Turkish IR scholars would be encouraged to address the problem of selection bias more systematically.

Third, the positions taken draw on the development of the Correlates of War $(\mathrm{COW})$ project and show how the aforementioned benefits materialized in the global IR community through the introduction of quantitative studies. Finally, we provide a brief review of some existing quantitative research in Turkish IR to illustrate how these potential benefits can be materialized in the local community.

\title{
The Current State of Turkish IR: Still a Fragmented Community?
}

In 2005, the Turkish Council of International Relations (UIK) started a series of biennial conferences to bring the Turkish IR community together in order to launch discussion on the local discipline's status, problems, and advancement. In the first of these meetings, the participants widely agreed that there was not enough communication within the community:

\begin{abstract}
We do not know about each other's studies. In other words, what they have been doing in Istanbul, we have no clue. In Istanbul, they do not know what we are doing in Ankara. I believe it is the same for universities in Anatolia. Some publishing companies that work in Istanbul do not even send their publications to Ankara, and vice versa (Aydin 2005, 28-29).
\end{abstract}

Another scholar added that the lack of communication was not restricted to that between universities in different cities, but also between universities within Istanbul (Hatipoğlu 2005). In a similar meeting that same year at the Middle East Technical University, another senior scholar bluntly stated that there was "no collaboration" between departments in Turkey (Eralp 2005).

Collaboration can, of course, refer to a number of things (Glänzel and Schubert 2005). It can be broadly related to social interaction, such as meetings

\footnotetext{
${ }^{3}$ Quantitative method refers to a number of processes related to empirical research, including a) collection of numerical data (e.g., foreign trade data), b) numerical data generation (e.g., event data), c) quantitative data analysis (statistical methods), and d) inference based on numerical calculations (e.g., game theory).
} 
Table 1. Top 10 most used words in articles by Turkey-based scholars in all ISI journals

\begin{tabular}{lrcr}
\hline Word & Rank & Number of articles & Percentage \\
\hline Turkey & 1 & 504 & 32.5 \\
Turkish & 2 & 311 & 20.1 \\
Policy & 3 & 117 & 7.5 \\
Political & 4 & 101 & 6.5 \\
Relations & 5 & 88 & 5.7 \\
Foreign & 6 & 87 & 5.6 \\
Case & 7 & 86 & 5.5 \\
European & 8 & 84 & 5.4 \\
Politics & 9 & 76 & 4.9 \\
Analysis & 10 & 64 & 4.1 \\
\hline
\end{tabular}

$N=1,550$.

and conferences, the institutionalization of the community in the form of professional associations, and the overall level of personal acquaintance among community members. Although this form of communication and "collaboration" may be beneficial for scientific productivity (Moody 2004), it is not necessarily essential. A more important form of collaboration is that of scientific interaction. Scientific interaction can basically take two forms: indirectly, when a researcher acknowledges the contributions (arguments, findings, or methods) of other researchers in one's own work, or directly, when two or more researchers conduct research together. The first form can be gauged by citation analysis and the second form by levels of co-authorship within a community.

Such scientific interaction requires a certain amount of agreement in research specialty. A disciplinary community's members will not be scientifically engaged with each other if their subject matters are so disparate that other scholars' works are irrelevant to one's own. In other words, if there is too much diversity within a community with respect to research interests, it is unlikely that an individual researcher would cite another scholar's work or that two or more researchers would consider conducting research together. Therefore, in looking to interpret the degree of collaboration with the Turkish IR disciplinary community, the first step is to consider whether there is at least sufficient overlap of subject matters to enable collaboration. To answer this initial question, we collected a sample of 1,550 articles by authors based in Turkey, published between 1980 and 2015 in all ISI indexed journals that are categorized as AS, IR, or PS. The top 10 most frequently used words in their titles are presented in Table 1. Not surprisingly, the most commonly used words in the titles of these articles are Turkish, Turkey, policy, political, relations, and foreign.

A narrower sample, which includes only IR articles ${ }^{4}$ published in four Turkeybased or Turkey-focused journals between 2008 and 2014 and written by authors based in Turkey, also reveals little variation in these top most-used words. Three journals were chosen to reflect the most acknowledged studies by Turkey's IR community; Bilig, Turkish Studies, and Uluslararası Ilişiler are the Social Sciences Citation Index (SSCI)-indexed top three PS, AS, or IR journals in which Turkeybased scholars published in the 2008-2014 period. Together, these journals' works have comprised half of all studies published by Turkey-based scholars since 2008. We also included New Perspectives on Turkey, a social science interdisciplinary journal, because it publishes a substantial number of influential IR articles. On average, 80 percent of all authors who published in these four journals are Turkeybased. Bilig, Uluslararası İliskiler, and New Perspectives on Turkey are Turkey-based

${ }^{4}$ IR articles are defined as having either explanans or explanandum as an international or transnational phenomenon (e.g., process, actor, structure, system, behavior). 
journals, whereas Turkish Studies is published by the Rubin Center for Research in International Affairs (formerly the Global Research in International Affairs [GLORIA] Center) in Israel. Table 2 presents the basic statistics on this narrower sample, and Table 3 presents the variation in most-used words.

Clearly, Turkey and its foreign and domestic politics are popular subject matters for these scholars publishing in both Turkey-based/focused journals and other SSCI journals as well. The results imply that, despite Turkey's growing interest in the outside world, Turkish IR is still predominantly "inward looking" (Turan 2012).

Despite having an extensively shared research subject, to what extent does the community of Turkey-based IR scholars scientifically engage with each other? As "one of the most tangible and well documented forms of scientific collaboration" (Glänzel and Schubert 2005, 257), levels of co-authorship may give a clue. According to a recent survey, the attitudes of Turkish IR scholars about co-authorship and its impact on one's professional achievement do not seem to differ widely from those of the rest of the world (Aydin and Yazgan 2013, 32), but in practice, differences emerge. Looking at the same set of 248 locally published IR papers, 26.8 percent were multiple-authored, and in the larger sample of 1,550, the ratio was 35.1 percent. These numbers are somewhat low compared to those in other social science communities. In American PS, the level of co-authorship has been consistently above 30 percent in all years since the late 1970 s and in recent years has reached close to 50 percent (Fisher et al. 1998; Chandra et al. 2006). In American sociology, more than 45 percent of articles annually have been co-authored since 1980, rising above 60 percent in the late 1990s (Moody 2004); and in Public Administration, the average percentage of co-authored articles rose from about 40 percent in 1973 to 84 percent by 2007 (Corley and Sabharwal 2010). Defined in terms of co-authorship, therefore, with the exception

Table 2. Top Turkish-based or Turkish-focused journals

\begin{tabular}{lccc}
\hline Journal & $\begin{array}{l}\text { Number of IR articles by } \\
\text { Turkey-based authors }\end{array}$ & $\begin{array}{l}\text { Number of articles by } \\
\text { Turkey-based authors }\end{array}$ & $\begin{array}{c}\text { Total number of } \\
\text { published articles }\end{array}$ \\
\hline Bilig & 44 & 310 & 340 \\
Uluslararasi Ilissiler & 113 & 125 & 162 \\
New Perspectives on Turkey & 19 & 68 & 89 \\
Turkish Studies & 75 & 175 & 240 \\
Total & 251 & 678 & 831 \\
\hline
\end{tabular}

Table 3. Top 10 most used words in articles by Turkey-based scholars in four Turkeybased/focused journals 2008-2014

\begin{tabular}{lccc}
\hline Word & Rank & Number of articles & Percentage \\
\hline Turkey & 1 & 87 & 35.1 \\
Policy & 2 & 50 & 20.2 \\
Turkish & 3 & 50 & 20.2 \\
Foreign & 4 & 42 & 16.9 \\
Relations & 5 & 41 & 16.5 \\
International & 6 & 35 & 14.1 \\
European & 7 & 21 & 8.5 \\
New & 8 & 19 & 7.7 \\
Security & 9 & 19 & 7.7 \\
Case & 10 & 17 & 6.9 \\
\hline
\end{tabular}

$N=248$. 
of the year 2010, the level of collaboration within Turkish IR can be considered lower than that of similar disciplines in the global academic community.

Turning to the other form of scientific interaction: To what extent do members of the Turkish IR community cite each other? Based on a Histcite analysis (Table 4), the larger sample of 1,550 articles contains a total local citation score of 865 and a total global citation score of 4,522. In other words, if we look at the ratio of Turkey-based citations to global community-based ones, on average each article in the larger pool is cited 0.56 times by other Turkey-based scholars and 2.92 times by other researchers, while in the smaller subset of articles in local journals $(n=248)$, each article is cited 0.35 times from within the community and 1.17 times from outside the community. These numbers suggest a level of engagement among Turkish IR scholars that seems low for a community that publishes in similar journals, is located in one country, and mostly shares a common research subject.

This impression is substantiated when we look at the citation practices in detail. Based on the ratio of local cited references (LCRs) to total cited references (TCRs), on average, only 2 percent of all citations in a given article are of other locally produced articles. This ratio drops to 1 percent when more narrowly defined Turkish IR is considered. Granted, the LCR/TCR ratio may be somewhat misleading as TCR counts include all references irrespective of publication type, such as, for example, books, newspapers, magazines, or non-ISI journals, whereas LCR counts do not include locally produced books, non-ISI journals, or articles that appeared in ISI-indexed publications in other areas (such as economics or history). Therefore, it is likely that the LCR/TCR ratio is actually somewhat higher than presented here. Nevertheless, since articles are the most cutting-edge publications related to a field, the fact that approximately 77 percent of all locally produced IR articles do not cite any other locally produced IR article (Table 5) corroborates the observations by senior scholars about limited scientific engagement within the community. Coupled with limited co-authorship, this limited engagement is suggestive of a fragmentation in Turkish IR.

\section{Theoretical and Methodological Diversity in Turkish IR}

Although there may be various personal or structural reasons for such limited engagement, a couple of factors endogenous to local research practices may also be relevant. For more engagement, researchers need a common background upon which they can base both their agreements and their disagreements. Whether for purposes of confirmation or contradiction and disapproval, researchers should have a mutually shared definition of what they do or do not agree about. As theories and paradigms have such pre-established definitions, it is easier for two researchers who share the same theoretical assumptions (or who can clearly point to distinct theoretical or paradigmatic disagreements) to interact scientifically. A limited engagement with theory in general might, therefore, be an impediment to scientific interaction. Researchers who use the same conceptual frameworks in their studies are encouraged to look at similar explanatory or constitutive

Table 4. Average number of cited references and citation scores

\begin{tabular}{lrr}
\hline The type of citation score & $N=1550$ & $N=248$ \\
\hline How many publications x cites (TCR) & 40.17 & 44.46 \\
How many times x is cited globally (GCS) & 2.92 & 1.17 \\
How many times x is cited locally (LCS) & 0.56 & 0.39 \\
How many local articles x cites (LCR) & 0.70 & 0.39 \\
LCR/TCR & 0.02 & 0.01 \\
\hline
\end{tabular}


Table 5. Percentage of local articles that cite other local articles

\begin{tabular}{lcc}
\hline Number of local references & $N=1,550$ & $N=248$ \\
\hline 0 & 0.69 & 0.77 \\
1 & 0.15 & 0.14 \\
$2-4$ & 0.12 & 0.07 \\
$>=5$ & 0.04 & 0.01 \\
\hline
\end{tabular}

variables that have an effect on what is being explained. As such, those researchers are more likely to go through the previous research informed by the same theoretical framework and cite it in their own work. This form of citation is usually a confirmative citation that affirms or builds upon the previous work. Engagement with one paradigm may also encourage engagement with rival paradigms, generally taking on the form of negational citations, that is, those reflecting criticism or repudiation of another study (Moravcsik and Murugesan 1975). When a study does not employ any particular framework, however, the authors may be less likely to cite other, more theoretically informed works.

Indeed, participants in the UIK conferences have also argued that few Turkish IR researchers have an interest in theory. The chief editor of Uluslarası Iliskiler Dergisi, the flagship journal of UIK, noted that most submissions of works based on empirical research in the form of AS are rejected from the journal because they lack any kind of conceptual framework. Similarly, a 2008 study on Turkish IR confirmed the chief editor's comments, describing the community's engagement with theory as "complex and uncomfortable" (Aydinli and Mathews 2008, 695). Interestingly, there seems to be at least a huge reported interest in more theoretically informed work. According to a recent UIK and TRIP survey (Aydin and Yazgan 2013, 18), 89 percent of Turkish IR scholars say they use a theoretical approach-a figure higher than the world average of 78 percent, the North American average of 79 percent, and the European average of 72 percent. There is also considerable diversity reported in theoretical approaches. Although realism is the most popular (26 percent), constructivism is a close second (24 percent), and no single approach seems to dominate the discipline. One Turkish respondent commented that the survey question ${ }^{5}$ is not a proper one since published work may incorporate different theories at different times. For example, s/he reported conducting research in the realist, post-structuralist, and constructivist traditions. The comment implies that, at least for some, theoretical diversity is embraced not only at the disciplinary level but at the individual level as well.

These figures imply that Turkish researchers are becoming increasingly interested in theoretically informed work, yet they seldom take part in global theoryshaping debates as there are only a very small number of researchers who do what is classified as "pure theory." ${ }^{6}$ Accordingly, only 3 percent of Turkish IR scholars report that their work is primarily analytic/non-formal conceptual" 7 rather than empirically oriented. Most of the "theoretically informed" work takes the form of application studies, that is, using concepts of core paradigms and testing those paradigms' theoretical insights against the case at hand. As an unusually high percentage of the Turkish respondents stated that IR studies should be motivated by a paradigm (22 percent vs. a global average of 4 percent), the end result often

\footnotetext{
${ }^{5}$ The wording of the question is "Which of the following best describes your approach to the study of IR? If you do not think of your work as falling within one of these paradigms, please select the category in which most other scholars would place your work" (Maliniak, Peterson, and Tierney 2012, 27).

${ }^{6}$ Pure theory consists of grand theories that account for large numbers of phenomena with no reference to specific regions or areas.

7 The analytic/non-formal conceptual category refers to "attempts to illuminate features of IR or IR theory without reference to significant empirical evidence or a formal model” (TRIP 2013, 13).
} 
becomes one of finding data, usually government supplied, that fit into the theory at hand, rather than generating data in an effort to answer a specific research question and only then searching for theories that might best help interpret those data. This practice turns Turkish IR into a hunter-gatherer society, in which one starts out with an argument and then selectively picks out numerical data to support that claim and leaves behind anything that is non-confirmatory.

As suggested by the citation records in the previous section, on a theoretical level, scholars and students of Turkish IR interact with Western-originated ideas far more than they interact with each other's ideas. In their research, a whopping 97 percent of Turkish IR scholars report "regularly" using materials written in foreign languages (Aydın and Yazgan 2013, 26), and more than half of the reading materials they use in their introductory-level IR classes are written by US-based authors. It is not surprising that they are far more likely to identify themselves with particular American or European schools of theory (Bilgin 2005; Aydinli and Mathews 2009; Yalçinkaya and Efegil 2009; Aydin and Yazgan 2010), rather than as an epistemic community of their own (Bilgin and Tanrisever 2009). Since science is a social enterprise, such exclusive theoretical engagement, combined with poor communication within the Turkish IR community, makes fruitful debate within Turkish IR unlikely. Although the level of reported theoretical diversity would seem to be sufficient for dialogue and debate, the lack of identification and familiarization with each other's work makes Turkish IR a fragmented community.

How might this fragmentation, defined in terms of exclusive theoretical engagement with the West and lack of scientific interaction within, be overcome? Why is theoretical diversity insufficient for generating debates? The answers might lie, at least in part, in the lack of diversity in another vital factor involved in research. Sezer (2005), a senior Turkish scholar, points out that although different theories are employed, most IR scholars in Turkey use more or less similar forms of gathering, presenting, and analyzing data, with the only identifiable differences emanating from the individual quality of the selection and collection of resources, differences in personal traits, and ideological differences. Consequently, she notes, studies by members of the Turkish IR community are all very much alike, even repetitive of each other. Others argue that there is an overreliance on historical methods, which mostly consist of chronological descriptions of events (Aydinli, Kurubaş, and Özdemir 2015).

We argue that apparent theoretical diversity and an undeniable proliferation of studies do not transform into debates because of this very lack of diversity in methods. It is important, therefore, to explore further the exact nature of this alleged lack of methodological diversity. Forty-three percent of Turkish TRIP survey respondents report using primarily qualitative methods, while 40 percent report engaging in policy analysis. ${ }^{8}$ Only 9 percent report using any quantitative methods and just 2 percent use formal modeling. Compared to the survey results from the global discipline, this degree of methodological diversity is in fact not very far from average (Bennett, Barth, and Rutherford 2003; Maliniak et al. 2011). Globally, 58 percent of TRIP respondents reported that qualitative methods are their primary research method, policy analysis makes up 17 percent, quantitative 15 percent, and formal modeling only 1 percent.

To explore this issue further and to examine in detail the salience of particular research methods in Turkish IR studies, we analyzed our subset of IR articles ${ }^{9}$ in four journals by Turkey-based scholars between the years 2008 and 2014. We first

\footnotetext{
${ }^{8}$ This category includes "articles whose primary purpose is the evaluation of options available to policymakers to respond to a specific policy problem" (TRIP 2013, 13).

${ }^{9}$ For automated HistCite Analysis, a sample of 248 articles was used. In the sample for our subsequent manual coding, we included three more articles, which were published in one of four journals at the time but not yet indexed by the Web of Science.
} 
Table 6. Methodology of articles by Turkey-based scholars

\begin{tabular}{lccccc}
\hline Articles & Quantitative & Formal theory & Meta-theoretical & Qualitative & Other \\
\hline Number & 16 & 12 & 28 & 207 & 1 \\
Percentage & 6.4 & 4.8 & 11.2 & 82.5 & 0.4 \\
\hline
\end{tabular}

Table 7. Methodology of articles in US-based journals

\begin{tabular}{lccccc}
\hline Articles & Quantitative & Formal theory & Meta-theoretical & Qualitative + descriptive & Other $^{13}$ \\
\hline Number & 2,955 & 1,116 & 1,405 & 4,432 & 767 \\
Percentage & 32.7 & 12.4 & 15.6 & 49.1 & 8.5 \\
\hline
\end{tabular}

Source: Maliniak et al. (2011).

considered "quantitative" in terms of four processes related to empirical research: (1) the use of readily available numerical data (such as foreign trade data); (2) numerical data generation (such as event data); (3) quantitative analysis of data (inferential statistics); and (4) inference based on numerical calculations (such as game theory).

We coded an article as actually using quantitative methods only when the author(s) used statistical modeling to infer a relationship between at least two variables operationalized in numerical form, and we coded those articles that used formal, derived mathematical equations or diagrams (such as game theoretic decision trees) as formal theory. However, we coded an article as qualitative if it used numerical, textual, or visual data to describe/explain/interpret contemporary or historical trends or events related to IR only through verbal argumentation. As such, the "Qualitative" category included case studies and descriptive studies, even if they referred to numerical data. The "other" category was applied to studies incorporating simulations and experiments. Since these four broad types of methods can be used simultaneously, any article that satisfied the relevant criteria could be coded as qualitative, quantitative, formal, other, or a combination of these. The last category, "meta-theoretical," consisted of attempts to elaborate on conceptual issues in IR theory without reference to empirical evidence or a formal model. An article could not be coded as meta-theoretical if it was coded as utilizing one of the other four methods.

Our findings showed that 82 percent of the 251 IR articles in our sample used qualitative methods, 6 percent used inferential statistics (regression), 5 percent used formal modeling, and one ( 0.4 percent) used the experimental method. Eleven percent of the articles were meta-theoretical. ${ }^{10}$ When we compare these results with the findings of a study about methodology in leading IR journals around the world (Maliniak et al. 2011), we find that the lack of methodological diversity is striking (Tables 6 and 7). Moreover, on a global level, the percentage of articles employing quantitative methods has increased every year from 1992 to 2006, reaching a total of 53 percent in 2006 (Maliniak et al. 2011, 451).

The apparent discrepancy between reported and actual practices seems to stem from the interpretation of what constitutes quantitative research. What our study revealed was that more than half of Turkey-based IR research ( 55 percent) does refer to numerical data descriptively to substantiate the arguments, but of these, only 12 percent actually employ any statistical methods.

${ }^{10}$ The articles that are exclusively qualitative comprise 79 percent. The total percentage exceeds 100 percent as 13 articles use multiple methods. 
This lack of methodological diversity can also be found in teaching practices. In Turkish undergraduate and graduate IR programs, there are no examples of separate qualitative and quantitative research methods classes; and the second debate on behavioralism, which identified the major fault lines between different methodological approaches in IR, is rarely discussed. This approach is somewhat surprising given that a large number of the younger generation of IR scholars pursued graduate studies abroad and have likely taken quantitative methods classes themselves. Bennett, Barth, and Rutherford (2003) found that 20 of the top 30 university graduate programs in PS in the United States require a course in quantitative methods in their curricula, while 7 more offer them as an elective. In Turkish universities, on the other hand, 95 percent of the undergraduate programs and 71 percent of the graduate programs (MA and $\mathrm{PhD}$ ) require a single, general course in research methods (Tepeciklioğlu 2013, 311), but none include courses designed for teaching specific quantitative or qualitative research methods. Although some universities require descriptive statistics classes at the undergraduate level, inferential statistics and advanced techniques are almost never taught at the graduate level. Even these basic statistics classes that are required in some undergraduate programs have come under criticism, with one author comparing their necessity for IR research to that of taking an accounting class (Kasim 2005).

Ultimately, the result is an extremely heavy reliance on qualitative methods in Turkish IR, and, as argued earlier, this single methodology is less conducive to the generation of debates. The further argument has also been made that greater use of quantitative methods could be instrumental in stimulating critical engagement within the local disciplinary community because of those methods' comparative advantage in being more explicit than qualitative methods. Goertz and Mahoney (2012), in a discussion of the problems they faced in comparing qualitative and quantitative methods, argue that with respect to quantitative research, they find it easier to "focus on explicit practices that follow well-established advice from the methodological literature. Quantitative research methods and procedures are often clearly specified, and quantitative researchers often quite explicitly follow these well-formulated methodological ideas" (Goertz and Mahoney 2012, 7). The same cannot always be said of qualitative research: "In general, qualitative methods are used far less explicitly when compared to quantitative methods. At this stage, in fact, the implicit use of methods could be seen as a cultural characteristic of qualitative research ... qualitative methods are often used unsystematically" (Goertz and Mahoney 2012, 8). Although qualitative analysis can certainly be as rigorous as quantitative analysis, this tendency for being implicit is not conducive to critical engagement. With conceptual and methodological explicitness, assumptions, theories, methods, and findings can be discussed, compared, challenged, or constructively criticized in a systematic manner. Dialogue is possible only if individual positions on method and theory are put forward and clarified. This clarity, we argue, is more likely to be attained if we incorporate more quantitative methods, as one of the major advantages of quantitative studies is the transparency in the operational definitions of concepts and the methods used in collecting and analyzing data, something arguably lacking in many qualitative studies (Moravcsik 2010, 2014; Elman and Kapiszewski 2014).

In its current state, most studies on Turkish foreign affairs (TFA) remain insular-either engagement with the global community fails to be adequately critical or scholarly engagement within the local community is insufficient. Therefore, with such limited engagement at the methodological or theoretical levels, either there are no debates in Turkey or those that exist seem to be increasingly shaped by political debates of national policy, with strong underlying ideological biases (Bilgin and Tanrisever 2009, 179). As such, Turkish IR seems to be a field of endeavor in which persuasion through verbal argumentation rather than informing through providing novel information is the norm. Interestingly, 
although these discussions tend to be based mainly on ideological preferences, they are also tinted with methodological criticisms, such that when results of research are politically unwelcome, the researchers may be accused instead of suffering from "misuse of theory" or of "slanting" the data (Yesiltas 2014, 35).

We propose, therefore, that the use of quantitative methods can enhance dialogue within Turkish IR in three interconnected but analytically identifiable ways:

Using quantitative methods encourages conceptual clarity as it compels the researcher to think
of the most appropriate ways to operationalize concepts.

When a researcher tries to quantify a concept, the first step is to devise quantifiable indicators, and this demands that the researcher provide a clear definition. The result of this process of definition through operationalization may not necessarily be considered by everyone as accurate or complete, but it is explicit. The operationalization process demanded by quantitative studies may thus serve to instill in researchers some degree of self-consciousness about the extent to which their definitions and choices are informed by theoretical assumptions, as well as their limitations in representing the concepts.

Quantitative methods generate standardized data. Accordingly, they allow for comparative as-
sessment of findings and make it possible to avoid shortcomings related to selective engagement
with idiosyncratic data.

Dealing with numerical data forces one to consider available options about what and how to measure. Most quantitative methods involve specific procedures and rules, including clarifying the selection of sources, coding procedures, and models and, ideally, providing justification for each of these. These procedures also involve specific precautions to ward off biases associated with, for example, source selection, sampling, and aggregation. All of this serves to generate standardized data, thereby making those data comparable to findings of other studies using the same method. Such common backgrounds in empirical data make it possible for newer studies to confirm or refute the previous findings of fellow researchers with shared subjects of interest and, ultimately, serve to foster intra- and inter-community discussion and debate.

The use of quantitative methods facilitates methodological clarity by offering a standardizedthough open for revision and improvement-procedure.

Quantitative methods could encourage scholarly debates on appropriate methodologies specifically because of the methodological and conceptual clarity that they are, arguably, better equipped with providing. At the most abstract level, quantitative methodologies can stimulate conversation about the best ways to study international phenomena. On a more practical level, debates about the shortcomings and benefits of quantification in general and individual quantitative methods in particular, as well as suggestions for improving those methods in various ways, may ensue. Specifically, because methodologies cannot be divorced from other philosophical positions on what is and how it can be known, we also hope that our call for quantitative methods at this juncture in the evolution of a still developing disciplinary community may itself trigger debates about ontology and epistemology within that community.

\section{Quantitative Research and Disciplinary Development in Global IR: The COW Project}

The main purpose of most academic quantitative research is to find statistical regularities. To this end, researchers collect and code data according to clearly 
defined procedures and in most cases use statistical methods to infer those regularities. In this section, we discuss the development of one such project, the COW, in an effort to clarify how this effort helped generate critical engagement within the global IR discipline.

The COW project began in 1963 at the University of Michigan (Dessler 1991). Inspired by a mathematical turn in behavioral sciences such as psychology (Geller 2004), COW became "one of the most ambitious social scientific projects of the late twentieth century" (Vasquez 1987, 35) and has spawned more than 350 studies over the years. ${ }^{11}$ From the very beginning, the project was at the center of critical engagement within the wider discipline. It is reasonable to argue that the second great debate of IR, although it had its origins elsewhere, was shaped by the COW project. As the research design, coding procedures, and methods of data analysis in the COW project evolved, so did the debate on the merits of a quantified IR. The project itself instigated additional philosophical debates about methodology and epistemology from the level of analysis problem (Singer 1961) to discussion about induction versus deduction.

One of the major contributions of the COW project was that it provided indicators and measurement techniques for a wide range of concepts by explicitly stating operational definitions of concepts used. These definitions and measurements were criticized and improved in later periods; ultimately, new measures for polarization, status inconsistency, concentration of power, and arms spending were devised. As Singer (1972) claimed, one must first describe the correlates of war before they can be explained, and such measures help to clarify what is meant by those concepts. A systematic empirical work, especially "the translation of ideologically loaded verbalization into operationally defined variables," may help scholars to discover "a considerable degree of convergence amongst theoretical models" (Singer 1981, 14). In the case of COW, those who shared certain common assumptions about methodology were able to improve and contribute to the discussion by pointing out shortcomings and possible improvements. For example, Zinnes (1967) reviewed the definitions of "balance of power" and compared them to Singer and Small's (1967) definition. She proposed an arguably more accurate measurement of alliance density in the international system so that studies might better account for the relationship between alliances and the onset of war. Most and Starr (1983) argued that war is an interactional concept and as such not attributable to properties of individual states. Therefore, they criticized research designs that try to account for wars as outcomes of national attributes. Similarly, Siverson and Sullivan (1983) criticized research designs that posit that an equal distribution of power leads to war, arguing that they use data not closely related to theory, that they reduce the variance in independent variables, and that they are subject to selective use of cases. Altfeld (1983) agreed with Wallace's (1979) definition of an arms race, but argued that his measurement was inaccurate and offered an alternative way. All of this criticism came from within the "scientific" paradigm, that is, from scholars sharing basic epistemological and methodological assumptions, and resulted in new efforts to improve the quality of the research being done (Colaresi and Thompson 2005).

For example, initially, Small and Singer (1976) defined war as sustained combat involving at least one organized armed force, resulting in a minimum of 1,000 battle-related fatalities among combat personnel. They differentiated between interstate (when all participants are sovereign states) and extra-systemic wars, in which one sovereign state fought against a "less than sovereign political entity" (Small and Singer 1976, 52). This distinction was itself based on a definition of membership in the international system for which they also made a list to clarify what they

\footnotetext{
${ }^{11}$ ICPSR Website shows 369 publications with references to Correlates of War data sets.
} 
meant in an operational sense by "sovereign state" (Singer and Small 1966b). By 2000, the typology had expanded: interstate wars remained the same; extra-systemic wars were now referred to as extra-state wars; the category of civil wars was expanded to intrastate wars (now including inter-communal wars); and a new category of nonstate wars was added (Sarkees and Schafer 2000).

Another major contribution was the systematic collection of data in order to test rival hypotheses about war. The project began with data on wars since 1815, both interstate and civil, and contained information about who fought, with whom, the time and duration, severity (number of battle deaths), regime type of the warring parties, and the identity of the initiator. Over the years, owing to criticisms voiced both from within and outside the project, the data set was expanded to incorporate data on alliances and diplomatic ties between states, the number of intergovernmental organizations, the national capabilities of the major powers, and contiguity. The collection of data on these other variables was shaped by rival arguments about the subject matter. For example, Singer and Small (1966a) released the first data set on international alliances (see also Gibler and Sarkees 2004). Wallace (1973) found that when there are too many or too few alliances, there are more wars. Bueno de Mesquita (1978) found that increasing tightness and more alliance bonds is associated with longer wars. Discussions also emerged about contiguity and the relative likelihood of war. Criticisms that war proneness has less to do with regime type but more with border contiguity (Stinnett et al. 2002) led Leng to investigate the relationship. A new data set on contiguity was established to test this rival claim and led to findings that the relationship between contiguity and war proneness is not straightforward, as disputes are less frequent in border zones, which have higher population densities, better transportation facilities, and more economic transactions (Leng 2002). Further debates around COW, especially on what constitutes war, led to the establishment of still more data sets, such as the Militarized Interstate Disputes (MID) (Gochman and Maoz 1984). Based on an understanding of the importance of individual decision makers, the Behavioral Correlates of War (BCOW) data set on bargaining techniques was established (Leng and Goodsell 1974; Leng 1987). As a consequence of a normative preference for a positive definition of "peace," rather than a negative one of "absence of war," some aspects of the COW project evolved into a subfield of peace studies, thereby changing the normative focus from "what causes war" to "how to establish peace" (Singer 1970).

Lastly, the COW project helped generate theories. One way it did this was by connecting the hypotheses that were tested and confirmed by COW data and transforming them into models. Two examples are Vasquez's steps-to-war model (1987) and Gochman's model on phases of interstate conflict (1993). Both of these studies connect the empirical findings of the project in a temporal manner to explain sequentially how and under what conditions a conflict becomes more likely, escalates, and transforms into war.

The second way in which COW helped theory development was by pointing to puzzles. One of the most robust findings of the project-that is, democracies do not fight each other, though they do fight wars as often as do nondemocratic states-has become a puzzle for researchers to explain and has given way to a separate democratic peace research program. The claim itself was not new. Babst (1964), a sociologist, had argued as far back as 1964 that no two democratic states had ever fought a war, but it took the COW project's quantified data (Small and Singer 1976) to reveal the puzzle by introducing data on nondemocratic states as well, that is, when compared to nondemocracies, democracies are not less war prone. The COW project brought the discussion to the forefront and provided the systematic, longitudinal data to spark real debate on the issue. This revival of interest "can be explained primarily by reference to the quality of the evidence 
and even the coherence of the theoretical structure on which it has been based" (Ray 2002, 107).

Indeed, the COW project is important not because the findings are undoubtedly objective or truthful but because these studies established some criteria according to which scholars could meaningfully evaluate and criticize each other's claims. Such criticisms led to, for example, a finer discussion of what exactly democracy or war is and how these concepts should be defined; epistemological debates on empiricism and induction; and discussions on rival variables, which led researchers to develop even more comprehensive data sets. The policy relevance of these findings also led to normative discussions, such as those on the legitimacy and efficacy of promoting democracy abroad to eliminate wars. The empirical background and explicit methodology that COW provided has made such wideranging debates possible.

An important consequence of this intense interaction inspired by COW was its success in community building. Apart from the core researchers and graduate students at the University of Michigan, other scholars later joined the project from both the United States and Europe (Vasquez 1987). With those engaged in secondary data analysis, the number of researchers who have networked through the project runs into the hundreds. This networking has become possible mostly because COW designated a clear temporal and spatial domain for research, encouraged and used clear definitions for concepts, and established common variable operationalizations and shared data, and all this made possible replication and constructive criticism. From the beginning, Singer and Small were determined to share the data within the wider discipline (Vasquez 1987, 110). Currently, COW's numerous cross-national and cross-time data sets are run by a loose network of researchers and institutions from around the world. Each host maintains a major data set and its documentation and ensures its consistency. This "coordinated decentralization" (Correlates of War Project 2015) helps researchers not only share the costs of data hosting but also sustain a sense of community.

Overall, this review on COW suggests that quantitative methods, especially those that are incorporated into large- $N$ data-building efforts, encourage researchers to better define concepts on an empirical level and be clear and explicit about their methodology. In turn, this offers scholars a standardized pool of evidence for testing rival claims, and the totality provides a foundation for fruitful debates that are less mired in misunderstandings about others' use of concepts. On a social level, the resulting heightened interaction serves to establish a sense of community and helps overcome local disciplinary fragmentation.

In the next section, to gauge whether the aforementioned benefits may be viable for a developing disciplinary community like that of Turkish IR, we review a few examples from the Turkish IR literature that either descriptively use numerical data to indicate dependent or independent variables or that statistically establish associations between them. We look at both descriptive and inferential studies, as we believe both play a role in producing the aforementioned benefits.

\section{Quantitative Research in Turkish IR}

Turkey's foreign affairs-focused political actors, the foreign actors they engage with, and the relations established have not only increased numerically in the last decade but have grown ever more complex. A comprehensive analysis is therefore difficult to make. Currently, Turkish IR community members are-to echo the old Indian parable-like blindfolded people trying to describe an elephant based solely on the limited information available to each of them individually. Hence, although their observations might be true for a specific time period, region, group of people, or type of relation, their conclusions differ enormously; they are not only disparate but sometimes conflicting. The qualitative methods that are 
commonly used in TFA studies clearly do offer some in-depth and detailed information; however, the introduction of more quantitative analytical methods could enable theorists to more easily and efficiently look at the subject matter in a longitudinal and holistic manner and provide opportunities for broad comparative analyses. In this section, we draw on a few examples of already existing quantitative research in Turkish IR in order to highlight three potential benefits of quantitative methods and the generation of numerical data.

\section{Clarifying Concepts: What Kind of Indicators, How to Define?}

To begin with, consider the notion of "foreign policy" as either a dependent or independent variable and how quantitative studies on TFA have defined it. One way is to define foreign policy as an outcome, that is, the results when particular foreign policy decisions are executed. In this sense, a commonly used indicator of Turkish foreign policy has been the volume and distribution of Turkish foreign trade across countries and regions. For example, Kiriş̧i and Kaptanoğlu (2011) ${ }^{12}$ rely on foreign trade data supplied by the Turkish Statistical Institute (TUIK) to argue that economic factors drive Turkish foreign policy. Although they suggest the trend began in the 1980s, Turkey's status as a trading state has become more prominent in the 2000s. Babacan (2010) also refers to changes in foreign trade data to establish that there has been a change in foreign policy. These studies use empirical data to describe changes in Turkey's foreign policy outcomes. In other words, they use foreign trade data as an indicator of the dependent variable, although their independent variables differ. For instance, Babacan (2010) refers to the global economic climate as an independent variable, while Kirişçi and Kaptanoğlu (2011) refer to economic rationality as an independent variable.

Still other studies define foreign policy as "foreign policy behavior" by decision makers. For example, Tezcür and Grigorescu (2014) show that the proportional change in the distribution of foreign trade volume may not be a proper indicator for assessing change in Turkish foreign policy behavior; they argue that Turkey's increasing foreign trade volume with the Middle East might be due to a change in oil prices. They use Turkey's voting patterns in the United Nations General Assembly over the past three decades as an indicator of Turkish foreign policy behavior and, accordingly, assess change in that voting. Another study that defines foreign policy as behavior is Civan et al. (2013), who used then Prime Minister Recep Tayyip Erdoğan's foreign visits as an indicator of foreign policy and investigated the effect of foreign visits on international trade by using a standard trade gravity model.

Hatipoğlu and Palmer (2014) also combine two quantitative indicators to measure Turkey's foreign policy change. The authors argue that as Turkey's capabilities increase, the country is more drawn to efforts to change the status quo. As indicators of foreign policy change, they use official foreign aid figures and NATO figures on the Turkish military's capital intensiveness. Use of foreign aid and the military's technological capability, the authors argue, are suitable indicators for gauging Turkey's foreign policy change as they are more effective as tools for instigating change than for maintaining the status quo. Therefore, although the researchers do not develop quantitative indicators for foreign policy per se, they use quantitative indicators for foreign policy change, at least as indicators of the "intent to change."

\footnotetext{
${ }^{12}$ They also use data from the Higher Election Board of Turkey on party vote distribution in the 2002 and 2007 general elections in the so-called Anatolian Tiger cities and data on the entry of persons from Turkey's neighborhood compiled from data obtained from the Foreigners Department of the Ministry of Interior and State Statistical Institute Annual Reports.
} 
A brief comparison of these studies gives clues about different meanings that might be associated with foreign policy. On the surface, all these studies are about Turkish foreign policy change, and all of them suggest that there has been a change, but the use of quantitative indicators, and the explicitness that those demand, makes it easier to understand what the authors mean when they use the concept of foreign policy (outcome or intention) and what aspect of foreign policy they are investigating.

Another important contribution these works have made is their attempt to clarify what is meant by the notion of the "West" or the "Middle East." According to their aggregation of data, Tezcür and Grigorescu (2014) identify the latter as Algeria, Bahrain, Egypt, Iran, Iraq, Jordan, Kuwait, Lebanon, Libya, Morocco, Oman, Qatar, Saudi Arabia, Sudan, Syria, Tunisia, the United Arab Emirates, and Yemen. Their comparison of Middle Eastern countries and Iran thus becomes less certain, as a decrease in foreign policy affinity with Iran would also decrease the measure of affinity with other Middle Eastern countries since the two variables are dependent by definition. This criticism is only possible because in aggregating the data, the authors were forced to explicitly state, rather than imply, what they meant by the "Middle East." Their propositions are open to debate, but it is the conceptual clarity demanded by the use of quantitative indicators that makes such debate possible.

\section{Standardized Data to Compare Empirical Claims}

A recent study shows that published articles that cover Turkey as a subject area are predominantly single case studies. Only 3 out of 627 articles published about Turkey between 1990 and 2014 in the top 40 ISI journals were large- $N$ studies, and 164 were comparative case studies (Somer 2014). Although single case studies may have certain strengths, such as providing in-depth, intensive information about a phenomenon or tracing the processes and mechanisms between causes and observed outcomes, they are limited in establishing external validity, that is, in the extent to which their results can be generalized to other cases (George and Bennett 2005). The evidence posited by each case study necessarily confirms the theoretical position of that study. For assessing a particular claim, one needs a sample of evidence that is different from the one used to build that claim. However, when each study is based on a separate collection of data and when the data collected are not standard across studies, comparing their findings is no longer entirely feasible as the observed convergence or divergence between findings may be related to differences in data collection procedures rather than to an actual substantive difference. Quantitative data-building research (especially large- $N$ studies), conversely, provides a standardized pool of evidence for testing hypotheses generated from existing theories across a multitude of cases.

Until such projects take off in a developing discipline such as Turkish IR, efforts can still be made to improve the external validity of single cases. The first step is to build up data on Turkey in a manner comparable to other studies so that the findings can be integrated into existing large- $N$ studies, even if the authors do not actively take part in the core research group. Using the same coding criteria, selecting sources that are analogous to those used by an existing large- $N$ study, and using the same analysis software or techniques can make the findings of an otherwise independent study comparable to a large body of other findings, as the data generated will be in standardized form. Two examples of such studies are those by Görener and Uçal (2011), who explore then Prime Minister Erdoğan's worldview and leadership style, and Kesgin (2013), who analyzes not only Erdogan's style but also that of all Turkish prime ministers since 1990. Both studies utilized the Leadership Trait Analysis method developed by Hermann 
(1980), a method consisting of systematic content analysis of decision makers' verbal records, using content analysis software. By using a well-established and clearly defined method, both studies were able to draw on earlier insights related to that method. For example, both chose to use so-called spontaneous material-rather than speeches and other prepared documents as proposed by the method's original developer-in order to avoid the shortcomings associated with analyzing the traits of speechwriters rather than leaders. Second, and more importantly, they can reliably compare their findings with other studies that have used the same method. For example, Görener and Uçal (2011, 365) were able to state that Erdoğan's traits resemble those of other Middle Eastern leaders, except in terms of self-confidence. Kesgin $(2013,146)$, on the other hand, was able to argue that when compared to Turkey's other leaders, Erdoğan's self-confidence was close to the mean.

The method used in these studies was explicit in terms of what source material should be chosen and how the data should be grouped, enabling the researchers to produce comparable results. The methodological clarity provided made it easier for their work to be part of a wider global comparative foreign policy network, and as such, their results have become part of a growing collection of data about leadership traits, which can then be of use to other researchers worldwide.

\section{Methodological Clarity: How to Measure?}

Quantitative studies can also trigger debates about methodology because of their comparative explicitness in collecting and measuring data. Consider two recent cases of originally created event data sets that have been designed specifically for understanding Turkey's foreign relations. The first of these attempts is an ongoing effort to generate an event data set that will cover the behaviors of all political actors in Turkey and their relationships both with each other and with foreign actors. Turkey's Foreign Affairs Dataset (TFAED) uses the CAMEO codebook developed by Schrodt (2012) and covers the years 1991-2014, using Agence France Presse reports as its data source. An offshoot of this is an effort to extend TFAED by coding Turkey-based Anatolia News Agency (AA) reports using TABARI (version 8.4b1) software (Tuzuner and Biltekin 2013).

A second event data set has been constructed covering the behaviors of governmental actors in Turkey in the years 2002-2012 (Beriker 2014). The project uses verbatim policy declarations and factual reported data on foreign policy actions as they appear in four Turkish-language and two English-language Turkey-based newspapers. The coding was done manually and contains 4,673 entries. Unlike TFAED, Beriker developed an original coding framework-the Foreign Policy Circumplex (FPC-TR) - that prescribes a different set of criteria in coding actors' behaviors.

Since both of these data sets measure Turkey's foreign policy behavior, a comparison between them may reveal various weaknesses or advantages of different aspects of event data research and possibly lead to the creation of better tools. For example, there is an ongoing discussion in the global/core disciplinary community over the validity and reliability of event data generated from open news sources for analyzing actors' behaviors (Taylor 2013). Several studies have questioned the reliability and validity of data sets from newspapers, arguing that selection bias (the subjective judgments of editors and reporters while deciding which events will be reported) and description bias (representation of news in a manner that will invoke strong audience interest) may impede such studies. Since these two Turkish data sets use different types of sources (domestic vs. international), their comparison could provide an important contribution to these debates. Another comparison could be made with respect to human coding versus 
machine coding. Both of these are potential methodological contributions with value for the global IR discipline.

Indeed, such methodological contributions in which local quantitative research may help instigate communication with the global discipline have materialized already in the case of the Hatipoğlu and Palmer (2014) study. In using the Composite Index of National Comparability (CINC) database, the authors discovered a measurement error; the size of Turkey's urban population had been miscalculated for the previous 8 years, resulting in an apparent decline in total capabilities. By corresponding with the hosts of the data set, they were able to get the data updated, a correction that would not have been possible if the coding and measurement standards of the CINC were not explicit.

\section{Conclusion}

Scholarly debates are key to a disciplinary community's academic and social development. One of the major conclusions of this evaluation has been that Turkish IR is a fragmented community that does not actively engage in scholarly debates. We argue that one way of overcoming such fragmentation and spawning debates in a developing disciplinary community can be to have more studies using quantitative research methods. The logic behind this call starts with the simple reality that in a discipline still dominated by qualitative research, the increased use of quantitative methodologies constitutes more diversity. More importantly, though, this call builds on the idea that quantitative methods produce methodological and conceptual clarity by suggesting specific step-by-step processes in the operationalization of concepts, the selection of sources and units of observation, and the analysis of data. This clarity can in turn allow for more systematic criticism, thereby generating fruitful debates and contributing to scientific progress and development within a maturing disciplinary community. Quantitative methods may therefore help Turkish IR build the foundations upon which synchronized theoretical and methodological development can be based.

Using quantitative methods may also help theoretical innovation not just locally but on a global disciplinary scale by increasing scholarly communication and collaboration. A group of scholars who use a particular method to work on different aspects of a certain subject will necessarily develop shared axioms about ontology, methodology, or both. Even such a partial, basic consensus can pave the way to more fruitful and progressive debates, as defining research groups is the most practical way to make clear who agrees (or disagrees) with whom and on what grounds. In particular, the generation of large- $N$ data sets, which are built and can be improved on through extensive collaborative work over time, is an experience that itself can be conducive to establishing and developing a community. This call should obviously not be construed as a proposed "enforced conversion" of researchers into a single group; indeed, the more communities the better. Ultimately, our call is not one for paradigmatic uniformity but an echo of those supporting theoretical and methodological diversity in the global discipline (noted most recently by Ferguson 2015), but our proposed method of achieving that diversity in the case of Turkish IR is through greater use of quantitative methods.

We therefore suggest, in a perhaps counterintuitive manner when encouraging diversity, that by working with clearly defined, quantitative methods, Turkish IR scholars can build bodies of consensus along various shared principles. The aim of using these methods and building these bodies of consensus is not to put an end to all disagreements and magically bridge the axiological and theoretical divergence in the subfield. On the contrary, we hope that the use of these methods and their outcomes will attract fierce criticism on all grounds-from the ontological level to those of data collection, analysis, and interpretation. Such systematic 
criticisms and meaningful interaction are extremely valuable as they provide fertile grounds for disciplinary progress.

Finally, it would be remiss of us not to mention the major criticisms against quantitative methods that come from critical approaches that argue that quantitative research methods are "instruments for structuring reality in certain ways" and that "under the guise of 'objectivity,' statistical procedures can serve to legitimize and universalize certain power relations because they give a 'stamp of truth' to the definitions upon which they are based" (Tickner 2005, 15). The neutrality arguably associated with quantitative research is used to avert questioning by others on moral grounds "when in fact the value sets and assumptions of the researchers tacitly guide problem definition and analysis" (Carley 1981, 20), especially with respect to policy-related research. When the data are obtained from formal institutions, their reliability is deemed even more questionable because of such institutions' interest in bolstering public perception of the government's or that specific institution's performance.

We would counter, first, that the use of quantitative methodologies does not necessarily indicate a commitment to an objectivist/neutral epistemology, as, by itself, use of quantitative methods does not entail any claims as to "the existence of objective knowledge, discrete variables or the appropriateness of dominant discourses of epistemology and ontology" (Sjoberg and Horowitz 2013, 105). Indeed, because of its explicitness, quantitative research may arguably help to reveal a researcher's preferences, values, and omissions and, hence, allow the reader to more readily evaluate the resulting research based on normative questions and political implications of such choices. Moreover, if critical theorists deal with "the questions that are not asked because of the lack of data" (Tickner 2014, $110 \mathrm{ft} .28$ ), then one way to generate more questions is to collect such data, particularly if ready-made government-collected data are found to be unreliable.

More importantly, perhaps, it is imperative to remember that critical theory is the product of a disciplinary community that has gone through many stages of development and that can afford to question those accumulated past experiences. Such questioning is even healthy in a context of established paradigms and ongoing intradisciplinary debates. In a still developing discipline like Turkish IR, taking to heart criticisms against a particular methodology or methods that have not yet been given a chance to be used, challenged, and revised would be preemptive and would rob that discipline of the chance to learn from that process. As with any evolving entity, a maturing discipline must learn from its mistakes; without that, it will unfortunately remain stunted and naïve.

\section{References}

Altfeld, Michael F. 1983. "Arms Races - Escalation? A Comment on Wallace.” International Studies Quarterly 27: 225-31.

Aydin, Mustafa. 2005. "Türkiye'de Uluslararası İlişkiler Eğitiminin Dünü, Bugünü.” Uluslararası Ílişiler 2: 25-29.

Aydin, Mustafa, and Korhan Yazgan. 2010. "Türkiye'de Uluslararası İlişkiler Akademisyenleri Araştırma, Ĕgitim ve Disiplin Değerlendirmeleri Anketi- (2009)." Uluslararasíl lişkiler 7: 3-42.

—. 2013. "Türkiye'de Uluslararası İlişkiler Akademisyenleri Eğitim: Araştırma ve Uluslararası Politika Anketi - 2011." Uluslararası İliskiler 9: 3-44.

Aydinli, Ersel, and Julie Mathews. 2008. "Periphery Theorizing for a Truly International Discipline: Spinning IR Theory out of Anatolia." Review of International Studies 34: 693-711.

—. 2009. "Turkey: Towards Homegrown Theorizing and Building a Disciplinary Community." In International Relations Scholarship around the World, edited by Arlene Tickner and Ole Waever. New York: Routledge.

Aydinli, Ersel, Erol Kurubaş, and Haluk Özdemir. 2015. Yöntem, Kuram, Komplo: Türk Uluslararast İlişkiler Disiplininde Vizyon Arayışlar. İstanbul: Küre. 
Babacan, Мehmet. 2010. "Whither Axis Shift: A Perspective from Turkey's Foreign Trade." SETA Policy Report No. 4. Accessed June 11, 2015. http://arsiv.setav.org/Ups/dosya/53018.pdf.

Babst, Dean V. 1964. "Elective Governments-A Force for Peace." Wisconsin Sociologist 3: 9-14.

Bennett, Andrew, Aharon Barth, and Kenneth R. Rutherford. 2003. "Do We Preach What We Practice? A Survey of Methods in Political Science Journals and Curricula." PS: Political Science $\mathcal{E}^{\circ}$ Politics 36: 373-78.

Beriker, Nimet. 2014. "Introducing the FPC-TR Dataset: Dimensions of AK Party Foreign Policy." Insight Turkey 16: 201-17.

Bueno De Mesquita, Bruce. 1978. "Systemic Polarization and the Occurrence and Duration of War." Journal of Conflict Resolution 22: 241-67.

Bılgin, PInAR. 2005. "Uluslararası İlişkiler Çalışmalarında 'Merkez-Çevre': Türkiye Nerede?" Uluslararasi İlişkiler 2: 3-14.

Bilgin, Pinar, and Oktay Tanrisever. 2009. "A Telling Story of IR in the Periphery: Telling Turkey about the World, Telling the World about Turkey." Journal of International Relations and Development 12: 174-9.

Carley, Michael. 1981. "Political and Bureaucratic Dilemmas in Social Indicators for Policy Making." Social Indicators Research 9: 15-33.

Chandra, Kanchan, Jennifer Gandhi, Gary King, Arthur Lupia, and Edward Mansfield. 2006. "Report of APSA Working Groupon Collaboration." Accessed June 11, 2015. http://www.avabiz.com/coau thorship.nsf/e272c1e4aad753b185257073003ae435/6c6e45389d6c215085257320003cae65/\$FILE/ CollaborationReport08-09-06.pdf.

Civan, Abdulkadir, Savaş Genç, Davut Taşer, and Sinem Atakul. 2013. "The Effect of New Turkish Foreign Policy on International Trade.” Insight Turkey 15: 107-22.

Colaresi, Michael P., and William R. Thompson. 2005. "Alliances, Arms Buildups and Recurrent Conflict: Testing a Steps-to-War Model.” Journal of Politics 67: 345-64.

Corley, Elizabeth A., and Meghna Sabharwal. 2010. "Scholarly Collaboration and Productivity Patterns in Public Administration: Analyzing Recent Trends." Public Administration 88: 627-48.

Correlates of War Project. 2015. "Correlates of War People: Data Hosts." Accessed June 12, 2015. http://www.correlatesofwar.org/people.

Dessler, David. 1991. "Beyond Correlations: Toward a Causal Theory of War." International Studies Quarterly 35: 337-55.

Elman, Colin, and Diana Kapiszewski. 2014. "Data Access and Research Transparency in the Qualitative Tradition.” PS: Political Science Eै Politics 47: 43-47.

Eralp, Atıla. 2005. "Türkiye'de Uluslararası İlişkiler Çalışmaları ve Eğitimi Paneli Tutanakları, ODTÜ, Komşuluk, Geçmiş, Bugün ve Gelecek Konferansı.” Uluslararası İlişkiler 2: 131-47.

Ferguson, Yale H. 2015. "Diversity in IR Theory: Pluralism as an Opportunity for Understanding Global Politics.” International Studies Perspectives 16: 3-12.

Fisher, Bonnie S., Craig T. Cobane, Thomas M. Vander Ven, and Francis T. Cullen. 1998. "How Many Authors Does It Take to Publish an Article? Trends and Patterns in Political Science." PS: Political Science E Politics 31: 847-56.

Geller, Daniel S. 2004. "Toward a Scientific Theory of War." In The Scourge of War: New Extensions on an Old Problem, edited by Paul. F. Diehl. Ann Arbor: University of Michigan Press.

George, Alexander L., and Andrew Bennett. 2005. Case Studies and Theory Development in the Social Sciences. Cambridge, MA: MIT Press.

Gibler, Douglas M., and Meredith Reed Sarkees. 2004. "Measuring Alliances: The Correlates of War Formal Interstate Alliance Dataset, 1816-2000.” Journal of Peace Research 41: 211-22.

Glänzel, Wolfgang, and András Schubert. 2005. "Analyzing Scientific Networks through CoAuthorship." In Handbook of Quantitative Science and Technology Research. Dordrecht: Kluwer Academic Publishers.

Gochman, Charles S. 1993. “The Evolution of Disputes.” International Interactions 19: 49-76.

Gochman, Charles S., and Zeev Maoz. 1984. "Militarized Interstate Disputes, 1816-1976 Procedures, Patterns, and Insights." Journal of Conflict Resolution 28: 585-616.

Goertz, Gary, and James Mahoney. 2012. A Tale of Two Cultures: Qualitative and Quantitative Research in the Social Sciences. Princeton, NJ: Princeton University Press.

Görener, Aylin Ş., and Meltem Ş. Ucal. 2011. "The Personality and Leadership Style of Recep Tayyip Erdoğan: Implications for Turkish Foreign Policy.” Turkish Studies 12: 357-81.

HatipoĞlu, Emre, and Glenn Palmer. 2014. "Contextualizing Change in Turkish Foreign Policy: The Promise of the 'Two-good' Theory." Cambridge Review of International Affairs, doi:10.1080/ 09557571.2014 .888538$. 
HatıpoĞLu, EsRa. 2005. "Türkiye'de Uluslararası İlişkiler Çalışmaları ve Eğitimi Toplantı Tutanakları, Dördüncü Oturum.” Uluslararası İliskiler 2: 117.

Hermann, Margaret G. 1980. "Explaining Foreign Policy Behavior Using the Personal Characteristics of Political Leaders." International Studies Quarterly 24: 7-46.

KAsım, Kamer. 2005. "Türkiye'de Uluslararası İişkiler Çalışmaları ve Eğitimi Toplantı Tutanakları, Dördüncü Oturum.” Uluslararası İlişkiler 2: 116.

Kesgin, Bariş. 2013. "Leadership Traits of Turkey's Islamist and Secular Prime Ministers." Turkish Studies 14: 136-57.

KirişĢ, Kemal, and Neslihan Kaptanoğlu. 2011. "The Politics of Trade and Turkish Foreign Policy." Middle Eastern Studies 47: 705-24.

Leng, Russell J. 1987. Behavioral Correlates of War Data: User's Manual. Ann Arbor, MI: Inter-University Consortium for Political and Social Research.

—. 2002. "Quantitative International Politics and Its Critics: Then and Now." In Evaluating Methodology in International Studies, edited by Frank P. Harvey and Michael Brecher. Ann Arbor: University of Michigan Press.

Leng, Russell J., And Robert A. Goodsell. 1974. "Behavioral Indicators of War Proneness in Bilateral Conflicts.” In Sage International Yearbook of Foreign Policy Studies. Beverly Hills: Sage.

Maliniak, Daniel, Amy Oakes, Susan Peterson, and Michael J. Tierney. 2011. "International Relations in the US Academy." International Studies Quarterly 55: 437-64.

Maliniak, Daniel, Susan Peterson, and Michael J. Tierney. 2012. TRIP around the World: Teaching, Research, and Policy Views of International Relations Faculty in 20 Countries. Accessed June 11, 2015. https://www.wm.edu/offices/itpir/_documents/trip/trip_around_the_world_(2011).pdf.

Moody, James. 2004. "The Structure of a Social Science Collaboration Network: Disciplinary Cohesion from (1963) to (1999)." American Sociological Review 69: 213-38.

Moravcsik, Andrew. 2010. "Active Citation: A Precondition for Replicable Qualitative Research.” PS: Political Science E Politics 43: 29-35.

—. 2014. "Transparency: The Revolution in Qualitative Research." PS: Political Science E̋ Politics 47: $48-53$.

Moravcsik, Michael J., and Poovanalingam Murugesan. 1975. "Some Results on the Function and Quality of Citations.” Social Studies of Science 5: 86-92.

Most, Benjamin A., and Harvey Starr. 1983. "Conceptualizing War: Consequences for Theory and Research.” Journal of Conflict Resolution 27: 137-59.

Ray, James L. 2002. "Reflections on Millennia: Old and New the Evolution and Role of Quantitative Approaches to the Study of International Politics." In Evaluating Methodology in International Studies, edited by Frank P. Harvey and Michael Brecher. Ann Arbor: University of Michigan Press.

Sarkees, Meredith Reed, and Philip Schafer. 2000. "The Correlates of War Data on War: An Update to (1997)." Conflict Management and Peace Science 18: 123-44.

Schrodt, Philip A. 2012. "CAMEO Conflict and Mediation Event Observations Event and Actor Codebook." Accessed June 11, 2015. http://data.gdeltproject.org/documentation/CAMEO. Manual.1.1b3.pdf.

Sezer, Duygu. 2005. "Türkiye'de Uluslararası İlişkiler Çalışmalarının Bilim Dalı OlarakGelişmesine Güncel ve Tarihsel Bir Bakış." Uluslararası İlişkiler 2: 30-42.

Singer, J. David. 1961. "The Level-of-Analysis Problem in International Relations." World Politics 14: $77-92$.

—. 1970. "From a Study of War to Peace Research: Some Criteria and Strategies." Journal of Conflict Resolution 14: 527-42.

—. 1972. "The 'Correlates of War' Project: Interim Report and Rationale." World Politics 24: 243-70.

. 1981. "Accounting for International War: The State of the Discipline." Journal of Peace Research 18: $1-18$.

Singer, J. David, and Melvin Small. 1966a. "Formal Alliances, 1815-1939: A Quantitative Description." Journal of Peace Research 3: 1-32.

- 1966b. "The Composition and Status Ordering of the International System: 1815-1940.” World Politics 18: 236-82.

—. 1967. "Alliance Aggregation and the Onset of War." In Quantitative International Politics: Insights and Evidence, edited by J. David Singer. New York: Free Press.

Siverson, Randolph M., and Michael P. Sullivan. 1983. "The Distribution of Power and the Onset of War." Journal of Conflict Resolution 27: 473-94.

Sjoberg, Laura, and Jefrrey Horowitz. 2013. "Quantitative Methods." In Critical Approaches to Security: An Introduction to Theories and Methods, edited by Laura J. Shepherd. London: Routledge. 
Small, Melvin, and J. David Singer. 1976. "The War-proneness of Democratic Regimes, 1816-1965." Jerusalem Journal of International Relations 1: 50-69.

Somer, Murat. 2014. "Theory-consuming or Theory-producing? Studying Turkey as a Theory Developing Critical Case.” Turkish Studies 15: 571-88.

Stinnett, Douglas M., Jaroslav Tir, Paul F. Diehl, Philip Schafer, and Charles Gochman. 2002. "The Correlates of War (COW) Project Direct Contiguity Data, Version 3.0." Conflict Management and Peace Science 19: 59-67.

Taylor, Charles L. 2013. "Data Quality for Measuring Political Protest and Government Change." AllAzimuth 2: 23-9.

Tepeciklıŏ̆Lu, Elem Eyrice. 2013. “Türkiye'de Uluslararası İlişkiler Eğitimi: Lisans ve Lisansüstü Ders Programlarının Karşılaştırmalı Bir Analizi.” Ege Akademik Bakış 13: 303-16.

Tezcür, Günȩ̧ M., and Alexandru Grigorescu. 2014. "Activism in Turkish Foreign Policy: Balancing European and Regional Interests.” International Studies Perspectives 15: 257-76.

Tickner, J. Ann. 2005. "What is Your Research Program? Some Feminist Answers to International Relations Methodological Questions.” International Studies Quarterly 49: 1-22.

- 2014. A Feminist Voyage through International Relations. New York: Oxford University Press.

Teaching, Research, and International Policy (TRIP) Project. 2013. "Codebook and User's Guide for TRIP Journal Article Database Revised April (2013).” Accessed June 11, 2015. https://grads. polisci.wisc.edu/rpowers/files/trip_codebook_(2013).pdf.

Turan, İlter. 2012. "Area and International Studies in Turkey: The Case of the United States." AllAzimuth 1: 50-63.

Tuzuner, Musa, and Gonca Biltekin. 2013. "A Pilot Study of Quantifying Turkey’s Foreign Affairs: Data Generation, Challenges and Preliminary Analysis." All-Azimuth 2: 47-70.

Vasquez, John A. 1987. "The Steps to War: Toward a Scientific Explanation of Correlates of War Findings.” World Politics 40: 108-45.

Waltz, Kenneth. 1979. Theory of International Politics. Reading, MA: Addison-Wesley.

Wallace, Michael D. 1973. "Alliance Polarization, Cross-Cutting, and International War, 1815-1964: A Measurement Procedure and Some Preliminary Evidence.” Journal of Conflict Resolution 17: 575604.

—. 1979. "Arms Races and Escalation: Some New Evidence.” Journal of Conflict Resolution 23: 3-16.

Yalçinkaya, AlaEddin, and ERTAN Efegil. 2009. "Türkiye'de Uluslararası İlişkiler Eğitiminde ve Araştırmalarında Teorik ve Kavramsal Yaklaşım Temelinde Yabancılaşma Sorunu." AkademikBakış 5: 207-30.

Yeşiltaş, Murat. 2014. "The New Era in Turkish Foreign Policy: Critiques and Challenges." Insight Turkey 16: 7-15.

Zinnes, DinA. 1967. "An Analytical Study of the Balance of Power Theories." Journal of Peace Research 4: 270-88. 